\title{
Association between duration of exclusive breastfeeding and nursing mothers' self-efficacy for breastfeeding
}

\author{
Associação da duração do aleitamento materno exclusivo \\ com a autoeficácia de nutrizes para amamentar \\ Asociación de la duración de la lactancia materna exclusiva con la \\ autoeficacia de las lactantes en el amamantamiento
}

How to cite this article:

Moraes GGW, Christoffel MM, Toso BRGO, Viera CS. Association between duration of exclusive breastfeeding and nursing mothers' self-efficacy for breastfeeding. Rev Esc Enferm USP. 2021;55:e03702. doi: https://doi.org/10.1590/S1980-220X2019038303702

Gécica Gracieli Wust de Moraes ${ }^{1}$

Marialda Moreira Christoffel ${ }^{2}$

Beatriz Rosana Gonçalves de

Oliveira Toso ${ }^{1}$

Cláudia Silveira Viera ${ }^{1}$

1 Universidade Estadual do Oeste do Paraná, Programa de Pós-Graduação em

Biociências e Saúde, Cascavel, PR, Brazil.

2 Universidade Federal do Rio de

Janeiro, Escola de Enfermagem Anna

Nery, Rio de Janeiro, RJ, Brazil.

\begin{abstract}
Objective: To verify the association of nursing mothers' self-efficacy for breastfeeding in the immediate postpartum period and six months after birth and obstetric and sociodemographic variables with the duration of exclusive breastfeeding. Method: Observational, longitudinal, prospective study which followed nursing mothers from the immediate postpartum period to the sixth month postpartum in a municipality in Southern Brazil. For data collection, a questionnaire with sociodemographic and obstetric variables and the scale Breastfeeding Self-Efficacy Scale - short form - were employed in the maternity ward and six months after birth. Inferential and descriptive statistics were employed. Results: A total of 158 nursing mothers have participated. The prevalence of exclusive breastfeeding in the sixth month was $36.70 \%$, out of which $77.34 \%$ have presented a high self-efficacy score. Sociodemographic factors had a negative impact on exclusive breastfeeding. Conclusion: High levels of self-efficacy favor exclusive breastfeeding; however, such factor, in isolation, is not decisive for exclusive breastfeeding. Self-efficacy should be identified during the pre-natal period through mothers' employment and marital status data to promote preventive actions against early weaning.
\end{abstract}

DESCRIPTORS

Breast Feeding; Self Efficacy; Continuity of Patient Care; Maternal-Child Nursing. 


\section{INTRODUCTION}

Breastfeeding $(\mathrm{BF})$ is a multifactorial theme of life in society which has been discussed for a long time with no success in expanding it into a widely accepted and adopted social practice. Various factors are related to BF, including the historical and sociocultural influence overwhelmingly observed along the years ${ }^{(1)}$, as well as personal aspects and aspects related to the health sector, which are the focus of this study. Despite the evident benefits of providing Exclusive Breastfeeding (EBF) until infants are six months old, the last three decades have seen a reduction in its predominance in the Brazilian population ${ }^{(2)}$. In Brazil, the prevalence of $\mathrm{EBF}$ is $41 \%$, a number which varies among its regions; prevalence in the South is $43.9 \%{ }^{(2)}$.

In Brazil, the promotion of EBF protection and support is permeated by public policies for its encouragement both in hospitalization and primary care ${ }^{(3-4)}$. However, in addition to policies, other aspects involving women from the pre-natal to the postpartum periods should be considered; these may influence both their intentions of breastfeeding and the duration of EBF.

Health conditions and difficulties - such as access to the health system, lack of information, excess of domestic work at home, return to work outside the home, latching difficulties, among other aspects ${ }^{(5-6)}$ - contribute to early weaning. Low education, family income ${ }^{(7-8)}$ and personal aspects, such as low self-confidence, distress, and maternal stress, also influence the success of EBF or lack thereof ${ }^{(9)}$.

Factors associated with the onset and continuity of $\mathrm{BF}$ analyzed in a meta-analysis ${ }^{(10)}$ referred to the previously mentioned sociodemographic and family aspects. A meta-analysis ${ }^{(11)}$ of Brazilian epidemiological studies has also showed that these aspects are strongly associated with early weaning. Low-weight infants who used pacifiers were also vulnerable to not being breastfed. The mothers' emotional and psychological aspects, however, were not analyzed in these reviews and are yet to be studied in a more comprehensive manner.

When evaluating EBF, it is important to jointly consider sociodemographic and family aspects, covering all the pre-birth period, from the pre-natal and along the puerperium periods, attempting at an early detection of possible prognosticators which make this process more difficult. These aspects are joined by the mothers' emotional and psychological factors, such as self-confidence for EBF, which was shown to be a strong predictor for both $\mathrm{BF}$ onset and its duration ${ }^{(12)}$.

The conception of self-efficacy as personal confidence to perform some task or achieving a specific goal in an efficient manner is adopted ${ }^{(13)}$. For the nursing mothers, this concept refers to their confidence or positive expectation in face of their knowledge and abilities to successfully breastfeed their children ${ }^{(14)}$.

Evaluating self-efficacy may be a strategy for health professionals to identify the risk for early weaning during the prenatal period and after birth. Investigations ${ }^{(15-16)}$ evaluating the BF self-efficacy of mothers have shown a higher score in specific instruments for measuring this maternal skill, characterizing the women as confident to breastfeed; these presented a higher duration of EBF. Thus, understanding this ability requires systematic and standardized evaluation guided by an instrument developed to this end, an important tool for daily perinatal care due to enabling the recognition of factors inherent to breastfeeding. Such tool favors actions for the promotion of mother and infant health ${ }^{(16)}$ from the perspective of health on $\mathrm{BF}$, given that its promotion, protection, and support require multisectoral action.

Thus, among the multiple factors affecting EBF, this study is dedicated to verifying the association of breastfeeding self-efficacy, sociodemographic and obstetric variables, with the duration of EBF by nursing mothers in the immediate postpartum period and six months after birth.

\section{METHOD}

\section{Design OF STUdY}

Observational, longitudinal, prospective study with a quantitative approach.

\section{LOCATION}

The location for this study was a school hospital in a middle-sized municipality in Southern Brazil and the residences of the participants included in this study. In 2016, 6,731 births took place in this municipality; out of these, 3,338 happened in this study's school hospital, 2,228 of which were by women with residence in this municipality.

\section{ENROLLMENT CRITERIA}

The study population comprised all women who gave birth from August to December 2017 in the hospital where this study was conducted.

The sample calculation accounted for the total of births in this hospital, adopting a 5\% significance level, 95\% confidence interval, and 0.8 sampling error margin. The initial calculated sample comprised 141 nursing mothers and was increased in $12 \%$ due to the risk of loss to follow-up.

This study included all literate women who gave birth with a pregnancy duration equals to or higher than 37 weeks and lived in the study's municipality. The excluded population comprised adolescents (aged up to 17 years, eleven months and 29 days - the legal definition of adolescence in Brazil) ${ }^{(17)}$, mothers of premature newborns, mothers of malformed newborns, mothers of newborns who required hospitalization in a neonatal intensive care unit, and mothers with complications (clinical and/or psychological intercurrences) which prevented them from answering the questionnaire and/or complications that kept them from breastfeeding (psychological, psychiatric, mammary, and/or clinical intercurrences, as reported in the medical records).

\section{Data collection}

In the data collection period, 158 women in the immediate postpartum period were approached in the school 
hospital's maternity ward. In the follow-up period, there was a sample loss of 30 (12.6\%) participants, detailed as follows: 30 days from postpartum, during a telephone follow-up, 138 participants answered; by the third month, 88 participants answered. Contact via an instant messaging application was thus also introduced and, in the sixth month, 128 participants answered. The losses to follow-up were due to change of address, municipality or telephone number or loss of child custody. Consequently, for data collection in the sixth month, domiciliary visits to 128 participants were conducted.

\section{DATA COlLECTION INSTRUMENTS}

The researchers accessed daily the maternity ward of the school hospital and verified the births of the previous 24 hours. After applying the inclusion and exclusion criteria so that participants would be enrolled in the study sample, the puerperal women were contacted and invited to participate in the investigation. Upon acceptance, they were informed of the research objectives and of the need of a new contact six months after hospital discharge. Subsequently, the data collection form with sociodemographic and obstetric variables was employed in the immediate postpartum period; it included the variables mother's age, education, occupation, family income, marital status, previous obstetric data, and current obstetric data. The mothers' BF self-efficacy was also evaluated. A systematic review ${ }^{(12)}$ compared and analyzed diverse instruments for measuring the mothers' BF self-efficacy and identified that the scale Breastfeeding Self-Efficacy Scale- short Form (BSES-SF), developed by Dennis $^{(18)}$ in 1999 , was the most employed among the analyzed instruments.

Based on this information and on the fact that this scale was validated in Brazil in 2008 by $\operatorname{Dodt}^{(19)}$ and was shown to be reliable, valid, and capable of verifying the mothers' perception of BF self-efficacy, the researchers elected BSES-SF as an instrument for measuring the confidence of nursing mothers while performing BF. Since this study's intention was to follow up the nursing mothers, both in the immediate postpartum period and in the sixth month of the infants' life, the scale was applied in two moments: 1 . between 24 and 48 hours postpartum, when the women were hospitalized in the study's maternity ward; 2 . in the sixth month after birth, considering the definition that $\mathrm{EBF}$ must be maintained until the infant is 180 days old.

The scale BSES-SF has 14 items divided into two domains ${ }^{(19)}$ : intrapersonal thoughts and breastfeeding technique (Chart 1 ) and the items are Likert-type. The scores are calculated by the sum of all the questions in which a given woman scores and the total ranges from 14 to 70 . In this classification, Efficacy is Low when the score ranges from 14 to 32 , Average from 33 to 51, and High from 52 to 70 . It may be applied or self-filled if the participant is capable of reading and writing ${ }^{(16,19)}$. The applied form of the scale was opted for in this study to establish a rapport for the domiciliary visit in the sixth month.
Chart 1 - Aspects evaluated by BSES-SF per domain - Brazil, 2019.

\begin{tabular}{|l|}
\hline \multicolumn{1}{|c|}{ INTRAPERSONAL THOUGHTS } \\
\hline Q1. I can always determine that my baby is getting enough milk. \\
\hline $\begin{array}{l}\text { Q2. I can always successfully cope with breastfeeding like other } \\
\text { challenging tasks (Succesfully overcomes breastfeeding and the other } \\
\text { life situations). }\end{array}$ \\
\hline $\begin{array}{l}\text { Q3. I always breastfeed my baby without using formula as a } \\
\text { supplement. }\end{array}$ \\
\hline $\begin{array}{l}\text { Q4. I always ensure that my baby is properly latched on for the whole } \\
\text { feeding. }\end{array}$ \\
\hline Q9. I can always be satisfied with my breastfeeding experience. \\
\hline Q14. I can always tell when my baby is finished breastfeeding. \\
\hline \multicolumn{1}{|c|}{ BREASTFEDING TECHNIQUE } \\
\hline Q5. I always manage the breastfeeding situation to my satisfaction. \\
\hline Q6. I always manage to breastfeed even if my baby is crying. \\
\hline Q7. I always keep wanting to breastfeed. \\
\hline $\begin{array}{l}\text { Q8. I can always comfortably breastfeed with my family members } \\
\text { present. }\end{array}$ \\
\hline $\begin{array}{l}\text { Q10. I can always deal with the fact that breastfeeding can be time- } \\
\text { consuming. (Even if it takes time, I want to breastfeed) }\end{array}$ \\
\hline $\begin{array}{l}\text { Q11. I always finish feeding my baby on one breast before switching } \\
\text { to the other. }\end{array}$ \\
\hline $\begin{array}{l}\text { Q12. I always continue to breastfeed my baby for every feeding. (for } \\
\text { every breastfeeding). }\end{array}$ \\
\hline $\begin{array}{l}\text { Q13. I always manage to keep up with my baby's breastfeeding } \\
\text { demands. (I organize my shower, sleep, and nourishment needs } \\
\text { according to the baby's breastfeeding). }\end{array}$ \\
\hline
\end{tabular}

Source: Dodt ${ }^{(19)}$.

The concept of EBF refers to when infants, until the sixth month of their lives, receive only maternal milk, provided directly from their mother's breast, milked, or from another source, with no other type of liquid or solid nourishment ${ }^{(20)}$. The variable self-efficacy for BF was defined as the confidence of the nursing mother on her capacity to breastfeed her child, encompassing the choice whether to breastfeed, how much effort to put on $\mathrm{BF}$, positive or negative thoughts during the process of $\mathrm{BF}$, and how she reacts emotionally to the difficulties of BF. The mother's self-efficacy for breastfeeding is influenced by four main sources of information, i.e., previous experiences with breastfeeding, vicarious experiences, verbal persuasion, and physiological responses such as fatigue, stress, and anxiety ${ }^{(18)}$.

\section{Data ANALYSIS AND TREATMENT}

The data of the BSES-SF scale (in the maternity ward and six months after hospital discharge) and the questionnaire with sociodemographic questions were tabulated into Excel - Microsoft for Windows 2010 with double inspection.

Descriptive statistics was used to represent the sample's characteristics, namely, Chi-Square Independence test and Adjusted Residual Analysis. To verify the association between breastfeeding duration with basal scores obtained in the self-efficacy scale and the quantitative variables of the sociodemographic data, a non-parametric test was applied for independent Mann-Whitney-U samples. For an association between the questions of BSES-SF and the duration of 
breastfeeding, a mathematical model was adjusted through the binary logistic regression method.

Once the final logistic regression model was decided for each of the model's objectives, the probabilities were calculated with the formula $\operatorname{Pr}=1 /[1+\mathrm{e}-(\alpha+\Sigma(\beta \mathrm{i}$ xi $)]$, in which $\alpha$ is the constant of the model.

\section{ETHICAL ASPECTS}

The project was approved by the Research Ethics Committee of Universidade Estadual do Oeste do Paraná in Opinion n. 2.195.270, dated August 1st, 2017. Those who accepted participation have signed the Informed Consent Form (ICF) in two copies. This research's development followed the Norms and Directives Regulating Research Involving Human Beings as established in Resolution n. 466/2012 by the National Health Council.

\section{RESULTS}

The data reveal that most study participants presented high scores of BF self-efficacy both in the postpartum period $(87.34 \%)$ and in the infants' sixth month of life (77.34\%). Although they have shown confidence in their ability to provide $\mathrm{EBF}$, its prevalence in the sixth month was inferior to $50 \%$. The EBF was negatively influenced by the sociodemographic factors family income, marital status, and return to work.

In Table 1, the BSES-SF scores are presented in two evaluation moments.

Table 1 - Scores in BSES-SF separated into high, average, and low self-efficacy for exclusive breastfeeding in the immediate postpartum period and in the sixth month after birth - Brazil, 2019.

\begin{tabular}{lcc}
\hline $\begin{array}{l}\text { BSES-SF } \\
\text { Scores }\end{array}$ & $\begin{array}{c}\text { Immediate } \\
\text { postpartum period } \\
(\mathbf{N}=\mathbf{1 5 8})\end{array}$ & $\begin{array}{c}\text { Follow-up in the sixth } \\
\text { month }(\mathbf{N}=128)\end{array}$ \\
\hline $\begin{array}{l}\text { Low self-efficacy } \\
(14 \text { to } 32 \text { points) }\end{array}$ & $1(0.63 \%)$ & $14(10.93 \%)$ \\
$\begin{array}{l}\text { Average self-efficacy } \\
\text { (33 to } 51 \text { points) }\end{array}$ & $21(13.29 \%)$ & $15(11.71 \%)$ \\
$\begin{array}{l}\text { High self-efficacy } \\
\text { (50 to } 70 \text { points })\end{array}$ & $138(87.34 \%)$ & $99(77.34 \%)$ \\
\hline
\end{tabular}

Based on the identification of a higher frequency of high BF self-efficacy scores among the participants, the association between scores obtained in each BSES-SF classification and duration of EBF was analyzed, as shown in Table 2.

Table 2 - Final scores for BSES-SF in the postpartum period and after six months and their association with maintenance of Exclusive Breastfeeding by the sixth month - Brazil, 2019.

\begin{tabular}{|c|c|c|c|c|c|}
\hline & & \multicolumn{4}{|c|}{ Final scores } \\
\hline & & Median & 1 $^{\text {st }}$ Quartile & $3^{\text {rd }}$ Quartile & p-value \\
\hline $\begin{array}{l}\text { Score in the } \\
\text { immediate } \\
\text { postpartum } \\
\text { period }\end{array}$ & & 59.0 & 54.0 & 64.0 & 0.739 \\
\hline \multirow{4}{*}{$\begin{array}{l}\text { Score after } \\
\text { six months }\end{array}$} & & Median & $1^{\text {st }}$ Quartile & $3^{\text {rd }}$ Quartile & \\
\hline & & 63.0 & 52.8 & 68.0 & \\
\hline & & \multicolumn{4}{|c|}{ Score after six months } \\
\hline & & Median & $1^{\text {st }}$ Quartile & $3^{\text {rd }}$ Quartile & \\
\hline \multirow{2}{*}{ EBF } & YES & 66.00 & 64.00 & 70.00 & \multirow{2}{*}{$<0.0001$} \\
\hline & NO & 55.00 & 37.00 & 63.75 & \\
\hline
\end{tabular}

Note: EBF - Exclusive Breastfeeding; p-value Mann-Whitney-U Test.

The final BSES-SF scores in the two evaluation moments were not statistically significant (0.739); in these, participants both in the postpartum period $(\mathrm{Md}=59)$ and in the sixth month of the infant's life ( $\mathrm{Md}=63)$ presented high $\mathrm{BF}$ efficacy. Thus, since delivery, the nursing mothers trusted their ability to breastfeed their child. A significant statistical difference was identified between the final BSES-SF scores in the sixth month among the participants who were in EBF and the scores of those who had weaned $(p<0.0001)$.

In this context, if a high BSES-SF score was related to the maintenance of EBF, an attempt at identifying the questions of the scale which could predict possible risk of early weaning was made, as shown in Table 3 and Figure 2. The answers to the scale's questions in the two evaluation moments are compared. Questions related to the intrapersonal domain (Q1, Q3, Q14) and breastfeeding technique (Q8, Q12) were statistically significant (Table 3).

Table 3 - Correlation between the scores obtained in the BSES scale questions in the immediate postpartum period and after six months - Brazil, 2019.

\begin{tabular}{|c|c|c|c|c|c|c|c|}
\hline & \multicolumn{3}{|c|}{ Immediate postpartum moment } & \multicolumn{3}{|c|}{ Six months } & \multirow[b]{2}{*}{ p-value } \\
\hline & Median & $1^{\text {st }}$ Quartile & $3^{\text {rd }}$ Quartile & Median & $1^{\text {st }}$ Quartile & $3^{\text {rd }}$ Quartile & \\
\hline Q1 & 4.0 & 3.0 & 4.0 & 5.0 & 3.8 & 5.0 & 0.003 \\
\hline Q2 & 4.0 & 3.0 & 5.0 & 5.0 & 3.0 & 5.0 & 0.523 \\
\hline Q3 & 5.0 & 4.0 & 5.0 & 3.0 & 1.0 & 5.0 & $<0.0001$ \\
\hline Q4 & 5.0 & 4.0 & 5.0 & 5.0 & 5.0 & 5.0 & 0.590 \\
\hline Q5 & 4.0 & 4.0 & 5.0 & 5.0 & 4.0 & 5.0 & 0.235 \\
\hline Q6 & 4.0 & 4.0 & 5.0 & 5.0 & 3.5 & 5.0 & 0.513 \\
\hline Q7 & 5.0 & 4.0 & 5.0 & 5.0 & 4.0 & 5.0 & 0.104 \\
\hline Q8 & 5.0 & 4.0 & 5.0 & 5.0 & 4.0 & 5.0 & 0.019 \\
\hline Q9 & 5.0 & 4.0 & 5.0 & 5.0 & 4.0 & 5.0 & 0.581 \\
\hline Q10 & 5.0 & 4.0 & 5.0 & 5.0 & 4.0 & 5.0 & 0.235 \\
\hline Q11 & 5.0 & 4.0 & 5.0 & 5.0 & 3.0 & 5.0 & 0.144 \\
\hline Q12 & 5.0 & 4.0 & 5.0 & 5.0 & 2.0 & 5.0 & $<0.0001$ \\
\hline Q13 & 4.0 & 4.0 & 5.0 & 5.0 & 3.0 & 5.0 & 0.538 \\
\hline Q14 & 4.0 & 3.0 & 5.0 & 5.0 & 4.0 & 5.0 & 0.006 \\
\hline Final Score & 59.0 & 54.0 & 64.0 & 63.0 & 52.8 & 68.0 & 0.739 \\
\hline
\end{tabular}

Note: Wilcoxon Test p-value.

Immediate postpartum moment: $\mathrm{N}=158$

After six months: $\mathrm{N}=128$ 
In the postpartum period, since the BF routine was still being established, the participants imagined that they would be able to identify whether the baby had suckled enough, as pointed by Q1. Six months from birth, nursing mothers were verified to be able to identify their baby's satisfaction after suckling $(\mathrm{p}=0.003)$. The use of formula as a supplement (Q3) was not planned by the participants immediately after giving birth; however, by the sixth month, the introduction of this supplement into breastfeeding had become more frequent $(\mathrm{p}=<0.0001)$. Question 14 (Q14), on whether mothers would be able to identify when their child was satisfied after suckling, showed that the participants had difficulties in recognizing their child's satisfaction promptly after birth; however, they showed knowledge on how to identify it by the sixth month $(\mathrm{p}=0.006)$.

Also, answers for Q8, on feeling comfortable while breastfeeding in the presence of other people, were mixed, which led to a statistically significant distribution ( $p=0.0019)$. Breastfeeding on demand (Q12) was statistically significant between birth and the sixth month; in this period, there was a reduction in $\mathrm{EBF}$ due to the introduction of formula milk $(\mathrm{p}=0.0001)$.

By using the model created through logistic regression to find associated factors between BSES-SF questions and the duration of $\mathrm{BF}$, probabilities were estimated, ordered, and plotted into a graph, resulting in the ROC curve shown in Figure 1.

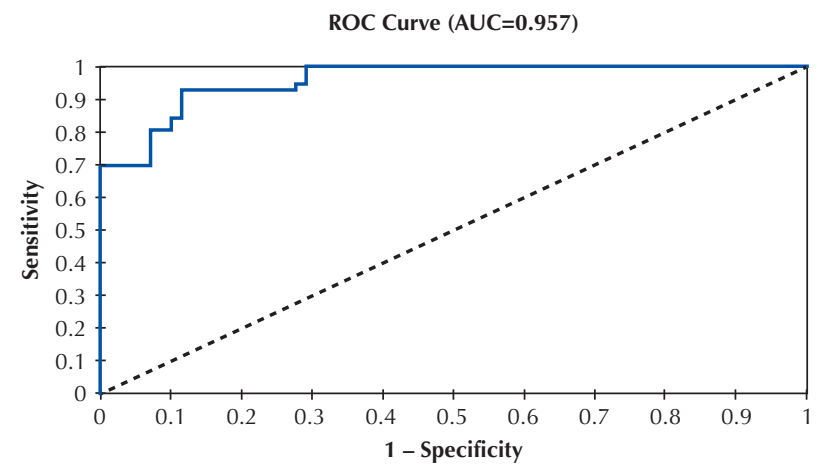

Figure 1 - ROC curve for the binary logistic regression model with predictive factors and association of Exclusive Breastfeeding - Brazil, 2019.

The area under the ROC curve shows that the model of estimated probabilities can predict approximately $95.7 \%$ of factors associated (Q3 and Q11) to the outcome (EBF by the infant's sixth month). The sensitivity of the adjusted model reflects its efficacy in identifying the nursing mothers who would be able to breastfeed exclusively until the sixth month, which is equivalent to $85.71 \%$ in this proposal. Its specificity reflects the efficiency in properly identifying mothers who would not breastfeed until the sixth month, which amounted to $88.24 \%$ in this study. In other words, the model can identify remarkably well the relation between women who will breastfeed until the infant's sixth month and those who will not.
Another important aspect for EBF refers to the sociodemographic conditions of nursing mothers, as presented in Table 4 , in which the association between these variables and the duration of $\mathrm{BF}$ is shown.

Table 4 - Sociodemographic variables related to Exclusive Breastfeeding by the sixth month - Brazil, 2019.

\begin{tabular}{|c|c|c|c|c|c|c|}
\hline & & \multicolumn{4}{|c|}{ Exclusive Breastfeeding } & \multirow{3}{*}{ p-value } \\
\hline & & \multicolumn{2}{|c|}{ NO } & \multicolumn{2}{|c|}{ YES } & \\
\hline & & $\mathrm{AF}$ & $\begin{array}{l}\mathrm{RF} \\
(\%)\end{array}$ & AF & $\begin{array}{l}\mathrm{RF} \\
(\%)\end{array}$ & \\
\hline \multirow{3}{*}{ Race } & White & 62 & 88.57 & 44 & 81.48 & \multirow{3}{*}{0.241} \\
\hline & Black & 1 & 1.43 & 4 & 7.41 & \\
\hline & Brown & 7 & 10.00 & 6 & 11.11 & \\
\hline \multirow{5}{*}{$\begin{array}{l}\text { Marital } \\
\text { Status }\end{array}$} & Unreported & - & - & 4 & 00.00 & \multirow{5}{*}{0.043} \\
\hline & Married & 38 & 54.28 & 31 & 53.45 & \\
\hline & Divorced & 1 & 1.42 & 0 & 0.00 & \\
\hline & Single & 9 & 12.85 & 1 & 1.72 & \\
\hline & $\begin{array}{l}\text { Domestic } \\
\text { Partnership }\end{array}$ & 22 & 31.42 & 26 & 44.83 & \\
\hline \multirow{2}{*}{ Working } & No & 25 & 35.71 & 33 & 56.90 & \multirow{2}{*}{0.020} \\
\hline & Yes & 45 & 64.28 & 25 & 43.10 & \\
\hline \multirow{5}{*}{$\begin{array}{l}\text { Education } \\
\text { level }\end{array}$} & $\begin{array}{l}\text { Incomplete } \\
\text { Primary }\end{array}$ & 7 & 10.00 & 5 & 8.62 & \multirow{5}{*}{0.727} \\
\hline & $\begin{array}{l}\text { Complete } \\
\text { Primary }\end{array}$ & 10 & 14.28 & 9 & 15.52 & \\
\hline & $\begin{array}{l}\text { Complete } \\
\text { Secondary }\end{array}$ & 42 & 60.00 & 37 & 64.00 & \\
\hline & $\begin{array}{l}\text { Complete } \\
\text { Higher }\end{array}$ & 9 & 12.85 & 7 & 12.06 & \\
\hline & Technical & 2 & 2.85 & 0 & 0.00 & \\
\hline \multirow{6}{*}{$\begin{array}{l}\text { Family } \\
\text { Income }\end{array}$} & No Income & 4 & 5.71 & 1 & 1.72 & \multirow{6}{*}{0.044} \\
\hline & $\begin{array}{l}\text { Up to } 1 \\
\text { Minimum } \\
\text { Wage }\end{array}$ & 5 & 7.14 & 12 & 20.70 & \\
\hline & $\begin{array}{l}1 \text { to } 2 \\
\text { Minimum } \\
\text { Wages }\end{array}$ & 26 & 37.14 & 21 & 36.20 & \\
\hline & $\begin{array}{l}2 \text { to } 3 \\
\text { Minimum } \\
\text { Wages }\end{array}$ & 18 & 25.71 & 6 & 10.34 & \\
\hline & $\begin{array}{l}\text { More than } \\
3 \text { Minimum } \\
\text { Wages }\end{array}$ & 7 & 10.00 & 4 & 6.90 & \\
\hline & Unreported & 10 & 14.28 & 14 & 24.14 & \\
\hline \multirow{2}{*}{$\begin{array}{l}\text { Type of } \\
\text { delivery }\end{array}$} & $\begin{array}{l}\text { Cesarean } \\
\text { section }\end{array}$ & 33 & 47.14 & 27 & 46.55 & \multirow{2}{*}{0.756} \\
\hline & Normal birth & 37 & 52.86 & 31 & 53.45 & \\
\hline \multirow{2}{*}{ Baby's sex } & Female & 32 & 45.71 & 29 & 50.00 & \multirow{2}{*}{0.684} \\
\hline & Male & 38 & 54.28 & 29 & 50.00 & \\
\hline \multirow{2}{*}{$\begin{array}{l}\text { Had } \\
\text { breastfed } \\
\text { previously }\end{array}$} & No & 31 & 44.28 & 20 & 34.48 & \multirow{2}{*}{0.301} \\
\hline & Yes & 39 & 55.70 & 38 & 65.52 & \\
\hline \multirow{2}{*}{$\begin{array}{l}\text { Orientation } \\
\text { on } \\
\text { breastfeeding }\end{array}$} & No & 42 & 60.00 & 41 & 70.68 & \multirow{2}{*}{0.275} \\
\hline & Yes & 28 & 40.00 & 17 & 29.31 & \\
\hline $\begin{array}{l}\text { EBF for } 6 \\
\text { months }\end{array}$ & - & 70 & 54.68 & 58 & 36.70 & - \\
\hline
\end{tabular}


Only $36.70 \%$ of nursing mothers were shown to be providing $\mathrm{EBF}$ in the sixth month after birth. The variables associated with EBF until the sixth month were marital status ( $p=0.043)$, return to work (0.020), and family income $(p=0.044)$. Participants who had no partner presented a higher frequency for non-maintenance of $\mathrm{EBF}$, and so did mothers who had an income of two to three minimum wages (Table 4). The highest frequency of EBF in the sixth month was observed among the participants who did not work outside the home and who reported an income of up to one minimum wage. The characteristics of pregnancy and birth and its association with the duration of EBF in the sixth month were not statistically significant (MannWhitney-U Test).

\section{DISCUSSION}

Among factors that influence EBF, this study has evaluated the self-efficacy of women for BF in two moments, relating this to their sociodemographic characteristics, and showed that, despite the high $\mathrm{BF}$ efficacy among participants, the prevalence of EBF in the follow-up was low. This finding confirms that the maintenance of EBF does not depend only on the mother's confidence on her ability to breastfeed, but that it is also multidetermined. The evaluation of self-efficacy must thus be related to the investigation of social and cultural aspects in the context of the nursing mothers. Together, these data will provide subsidies for health professionals to plan care of mother-infant health, because, if EBF was below the expected in the follow-up even with a high BF efficacy, it is necessary to support efforts to improve all their intervening factors. Exclusive breastfeeding and $\mathrm{BF}$ self-efficacy were also low among puerperal women in a maternity ward in Cyprus, which suggests the need for interventions that increase BF self-efficacy and train mothers to start breastfeeding in the maternity ward ${ }^{(21)}$.

Although the participants felt confident to perform BF after giving birth, marital status, work, and family income were factors associated with early weaning in this study. Specially among participants with no partner, those who were family providers and had to return to work soon after childbirth, the data were similar to those of other authors ${ }^{(22-23)}$. In a study of factors associated with EBF for the first six months, a significant statistical association between return to work and EBF was identified ${ }^{(2)}$. This was also observed in other countries, such as among Chinese women who breastfed, for whom returning to work was an indicator responsible for $47.6 \%$ of early abandonment of $\mathrm{BF}^{(23)}$. Thinking of strategies that help working nursing mothers to continue to breastfeed must be a conduct present in society and, specifically, in health services.

In the evaluated context, the protective factor for EBF maintenance was family support, offered specifically by the presence of a partner. Interventions for the promotion of $\mathrm{EBF}$ must concentrate on social support networks that include the father and other family members ${ }^{(24-26)}$. Thus, health professionals must be aware to recognize early that nursing mothers with no partner are more vulnerable to difficulties with EBF.

Despite the lower prevalence of EBF in the sixth month, the percentage of participants who presented a higher $\mathrm{BF}$ self-efficacy score since childbirth trusted their ability to start breastfeeding ${ }^{(18)}$. Thus, the participants presented expectations and positive beliefs on their capacity for breastfeeding and were able to maintain EBF until the infant was six months old, data found also in a systematic review ${ }^{(12)}$. In this sense, employing BSES-SF in the nursing clinical practice or another efficient tool to identify maternal behaviors during $\mathrm{BF}$ which may interfere with this process and provide strategies to grant success ${ }^{(19,27-29)}$ enables recognizing nursing mothers with a risk of early EBF interruption due to low $\mathrm{BF}$ self-efficacy ${ }^{(14)}$. However, this evaluation cannot be dissociated from cultural and sociodemographic factors in the context of the nursing mothers, given that, in this study, even those with a high efficacy stopped practicing EBF because of other intervenient sociodemographic factors.

Some specific questions of BSES-SF may contribute to the nurse's identification of mothers with a potential for maintaining EBF and those subject to early weaning. One of these is related to feeding with both breasts, which in this study was predictive of EBF until the sixth month of the infant's life, when the nursing mothers completely agreed with this question. However, the question on the nonintroduction of formula as a supplement for the infant was predictive of early weaning among mothers who expressed complete disagreement with the statement. The questions whose answers were statistically significant integrate the intrapersonal domain, overlapping with those of the domain of breastfeeding technique per se. Social and personal aspects have influenced more the success of BF or lack thereof.

A study ${ }^{(30)}$ has demonstrated that instruments have been used to evaluate $\mathrm{BF}$ duration commonly with the objective of predicting which nursing mothers are at highest risk of early weaning. Among these, BSES-SF has pointed a significant difference in women who breastfed exclusively and those who used exclusively milk formula to feed their child in the sixth week after birth. Another more recent study ${ }^{(14)}$ indicates that the BSES-SF scale can be a reliable tool in recognizing puerperal women at highest risk of early weaning. However, no studies analyzing the association between the questions of this scale and the prediction of highest risk of weaning along six months was identified.

More than encouraging BF self-efficacy among nursing mothers, it is fundamental that the health team consider aspects from the sociodemographic context which are negative predictors of EBF, such as family relations, given that these are a support for nursing mothers during the $\mathrm{BF}$ process and help with the maintenance of EBF.

The relevance of this study consists in its contribution to the academic, professional, and social areas by presenting personal - such as self-efficacy -, social, and family aspects of the nursing mothers which may be integrated into BF management from hospitalization to primary care health units. The questions associated with a higher risk for early weaning should be implemented as predictors of this risk during the evaluation of nursing mothers to guide strategy planning in BF promotion. Also, this study enables the evaluation of educational interventions on $\mathrm{BF}$ implemented during pregnancy and the provision of subsidies for building strategies in groups of nursing mothers with lower postpartum 
self-efficacy scores, associated with the factors not having a partner, having low family income, and having to return to work, which may help them overcome difficulties and facilitate longer continuity of EBF.

Actions for BF promotion are recommended to start during pregnancy, since prenatal counselling, in an intervention study, was shown to be efficient for increasing the mothers' $\mathrm{BF}$ self-efficacy. The nursing mothers with the highest selfefficacy were able to solve most problems during the BF process $^{(31)}$. As a predictor of $\mathrm{EBF}$, this aspect may provide subsidies for nursing mothers to manage BF, associated with the help and support from their social network and from the primary care health professionals who can contribute to minimize the negative effects of other aspects which limit the process of breastfeeding.

This study is limited to a specific phenomenon in a particular population in one service; space and time limitations must be considered. Thus, although the theme breastfeeding is not new and has been widely studied, the problems of EBF persist in time. Thus, recommendations include research which encompass evaluation instruments, such as BSES-SF, the family's role in this context, and preparation strategies for health professionals in promoting $\mathrm{EBF}$, to avoid that the professional care provided be restricted to intervention assistance.

\section{CONCLUSION}

An association between higher scores of BF efficacy and higher duration of EBF was identified. However, maternal confidence to breastfeed alone does not constitute a predictive factor for increased prevalence of EBF six months from childbirth, given that sociodemographic variables, such as partner absence, return to work, and family income of two to three minimum wages were predictors of early weaning. The nursing mothers who during BSES application expressed disagreement with the need for feeding with both breasts and the non-introduction of formula as a complement did not maintain EBF to the sixth month of the infant's life. Nursing mothers should receive, in addition to family support, the support of health services and other sectors of society, being safeguarded by effective institutional policies for strengthening breastfeeding from conception, extending to the first years of the infants' life.

\section{RESUMO}

Objetivo: Verificar a associação entre a autoeficácia para amamentação de nutrizes no pós-parto imediato e aos seis meses após o parto e variáveis sociodemográficas e obstétricas com a duração do aleitamento materno exclusivo. Método: Estudo observacional, longitudinal prospectivo, que acompanhou nutrizes desde o pós-parto imediato até o sexto mês pós-parto em município da região sul do Brasil. Empregou-se, para coleta de dados, formulário com variáveis sociodemográficas e obstétricas e a escala Breastfeeding Self-Efficacy Scaleshort form - na maternidade e aos seis meses pós-parto. Foi utilizada análise estatística descritiva e inferencial. Resultados: Participaram 158 nutrizes. A prevalência do aleitamento materno exclusivo no sexto mês foi de 36,70\%, dos quais 77,34\% apresentaram alto escore de autoeficácia. Fatores sociodemográficos influenciaram negativamente o aleitamento materno exclusivo. Conclusão: Altos níveis de autoeficácia favorecem a amamentação exclusiva; contudo, tal fator, isoladamente, não é decisivo para o aleitamento materno exclusivo. É necessário identificar a autoeficácia no pré-natal, juntamente com dados sobre o trabalho materno e o estado civil, para promover ações para prevenir o desmame precoce.

\section{DESCRITORES}

Aleitamento Materno; Autoeficácia; Continuidade da Assistência ao Paciente; Enfermagem Materno-Infantil.

\section{RESUMEN}

Objetivo: Verificar la asociación entre la autoeficacia de la lactancia materna en el posparto inmediato y a los seis meses del parto y las variables sociodemográficas y obstétricas con la duración de la lactancia materna exclusiva. Método: Estudio observacional, longitudinal y prospectivo que acompañó a las lactantes desde el posparto inmediato hasta el sexto mes posparto en una ciudad del sur de Brasil. Para la recogida de datos se utilizó un formulario con variables sociodemográficas y obstétricas y la Breastfeeding Self-Efficacy Scale - short form - en la maternidad y a los seis meses del posparto. Se utilizó el análisis estadístico descriptivo e inferencial. Resultados: Participaron 158 lactantes. La prevalencia de la lactancia materna exclusiva al sexto mes fue del 36,70\%, de los cuales el 77,34\% presentó una alta puntuación de autoeficacia. Los factores sociodemográficos influyeron negativamente en la lactancia materna exclusiva. Conclusión: Los altos niveles de autoeficacia favorecen la lactancia materna exclusiva; sin embargo, este factor por sí solo no es decisivo para la lactancia materna exclusiva. Es necesario identificar la autoeficacia prenatal, junto con los datos sobre el trabajo y el estado civil de las madres, para promover acciones de prevención del destete precoz.

\section{DESCRIPTORES}

Lactancia Materna; Autoeficacia; Continuidad de la Atención al Paciente; Enfermería Maternoinfantil.

\section{REFERENCES}

1. Alvarenga SC, Castro DS, Leite FMC, Brandão MAG, Zandonade E, Primo CC. Fatores que influenciam o desmame precoce. Aquichan. 2017;17(1):93-103. doi: https://10.5294/aqui.2017.17.1.9

2. Boccolini CS, Boccolini PMM, Monteiro FR, Venâncio SI, Giugliani ERJ. Tendência de indicadores do aleitamento materno no Brasil em três décadas. Rev Saúde Pública. 2017;51:108. doi: https://doi.org/10.11606/S1518-8787.2017051000029

3. Victora CG, Bahl R, Barros AJDJ, França GVA, Horton S, Krasevec J, et al. Breastfeeding in the 21 st century: epidemiology, mechanisms, and lifelong effect. Lancet. 2016;387:475-90. doi: https://doi.org/10.1016/S0140-6736(15)01024-7

4. Paraná. Secretaria de Estado da Saúde. Linha Guia mãe paranaense [Internet]. Curitiba (PR); 2014 [citado 2019 out. 10]. Disponível em: https://crianca.mppr.mp.br/arquivos/File/publi/sesa_pr/mae_paranaense_linha_guia.pdf

5. Brandão APM, Almeida APR, Silva LCB, Verde RMV. Aleitamento materno: fatores que influenciam o desmame precoce. Rev Cient FacMais. 2016;5(1):1-24. 
6. Andrade HS, Pessoa RA, Donizete LCV. Fatores relacionados ao desmame precoce do aleitamento materno. Rev Bras Med Fam Comunidade. 2018;13(40):1-11. doi: http://dx.doi.org/10.5712/rbmfc13(40)1698

7. Uema RTB, Souza SNDH; Mello DF, Capellini VK. Prevalência e fatores associados ao aleitamento materno no Brasil entre os anos 1998 e 2013: revisão sistemática. Semina: Cienc Biol Saúde (Londrina). 2015;36(1 Supl):69-78. doi: 10.5433/1679-0367.2014v35n2p349

8. Santana GS, Giugliani ERJ, Vieira TO, Vieira GO. Factors associated with breastfeeding maintenance for 12 months or more: a systematic review. J Pediatr (Rio J). 2018;94(2):104-22. doi:10.1016/j.jped.2017.06.013

9. Vieira ES, Caldeira NT, Eugênio DS, Lucca MM, Silva IA. Breastfeeding self-efficacy and postpartum depression: a cohort study. Rev Latino Am Enfermagem. 2018;26:e3035. doi: http://dx.doi.org/10.1590/1518-8345.2110.3035

10. Cohen S, Alexander DD, Krebs NF, Young BE, Cabana MD, Erdmann P, et al. Factors associated with breastfeeding initiation and continuation: a meta-analysis. J Pediatr. 2018;203:190-6.e21. doi: https://doi.org/10.1016/j.jpeds.2018.08.008

11. Pereira-Santos M, Santana MS, Oliveira DS, Nepomuceno Filho RA, Lisboa CS, Almeida LMR, et al. Prevalence and associated factors for early interruption of exclusive breastfeeding: meta-analysis on Brazilian epidemiological studies. Rev Bras Saúde Mater Infant. 2017;17(1):59-67. doi: doi.org/10.1590/1806-93042017000100004

12. Tuthill EL, McGrath JM, Graber M, Cusson RM, Young SL. Breastfeeding self-efficacy: a critical review of available instruments. J Hum Lact. 2016;32(1):35-45. doi:10.1177/0890334415599533

13. Ramachaudran VS. Encyclopedia of human behavior. New York: Academic Press; 1994. Bandura A. Self-Efficacy, p. 71-81.

14. Rocha IS, Lolli LF, Fujimaki M, Gasparetto A, Rocha NB. Influência da autoconfiança materna sobre o aleitamento materno exclusivo aos seis meses de idade: uma revisão sistemática. Ciênc Saúde Coletiva. 2018;23(11):3609-19. doi: https://doi.org/10.1590/1413812320182311.20132016

15. Mituki DM, Tuitoek PJ, Varpolatai A, Taabu I. Translation and validation of the breast feeding self-efficacy scale into the Kiswahili language in resource restricted setting in Thika - Kenya. Glob J Med Pub Health [Internet]. 2017 [cited 2019 Oct 12];6(3):1-9. Available from: http:// repository.mut.ac.ke:8080/xmlui/handle/123456789/3643

16. Oriá MOB, XLB. Tradução e adaptação cultural da Breastfeeding Self-Efficacy Scale para o português. Acta Paul Enferm. 2010;23(2):23038. doi: http://dx.doi.org/10.1590/S0103-21002010000200013

17. Brasil. Lei $n^{\circ}$ 8.069, de 13 de julho de 1990. Dispõe sobre o Estatuto da Criança e do Adolescente e dá outras providências [Internet]. Brasília; 1990 [citado 2019 out. 10]. Disponível em: https://www2.camara.leg.br/legin/fed/lei/1990/lei-8069-13-julho-1990-372211publicacaooriginal-1-pl.html

18. Dennis CL. Theoretical underpinnings of breastfeeding confidence: a self-efficacy framework. J Hum Lact. 2003;15:195-201. doi: $10.1177 / 089033449901500303$

19. Dodt RCM. Aplicação e validação da Breastfeeding Self-EficacyScale - Short Form (BSES-SF) em Puérperas. Rev Rene [Internet]. 2008 [citado 2019 set. 11];9(2):165-7. Disponível em: http://www.periodicos.ufc.br/rene/article/view/5058/3712

20. Brasil. Ministério da Saúde. Guia alimentar para crianças brasileiras menores de dois anos [Internet]. Brasília, Ministério da Saúde; 2019 [citado 2019 out. 10]. Disponível em: http://189.28.128.100/dab/docs/portaldab/publicacoes/guia_da_crianca_2019.pdf

21. Hadjiona V, Middleton N, Kouta C, Hadjigeorgiou E, Lambrinou E, Kolokotroni O. Cyprus mothers' breast feeding self-efficacy and their perceptions about the implementation of the '10 steps' in the first 48 hours after birth. Midwifery. 2016;36:43-52. doi: https//10.1016/j. midw.2016.02.021

22. Rozga MR, Kerver JM, Olson BH. Self-reported reasons for breastfeeding cessation among low-income women enrolled in a peer counseling breastfeeding support program. J Hum Lact. 2015;31(1):129-37. doi: 10.1177/0890334414548070

23. Sun K, Chen M, Yin y, Wu L, Gao L. Why Chinese mothers stop breastfeeding: Mothers' self-reported reasons for stopping during the first six months. J Child Health Care. 2017;21(3):353-63. doi: 10.1177/1367493517719160

24. Valizadeh S, Hosseinzadeh M, Mohammadi E, Hassankhani H, Fooladi MM, Schmied V. Addressing barriers to health: experiences of breastfeeding mothers after returning to work. Nurs Health Sci. 2017;19(1):105-11. doi: 10.1111/nhs.12324

25. Faridvand F, Mirghafourvand M, Malakouti J, Charandabi SMA. Relationship between social support and breastfeeding self-efficacy among women in Tabriz, Iran. Brit J Midwifery. 2017;25(2). doi: https://doi.org/10.12968/bjom.2017.25.2.103

26. Prates LA, Schmalfuss JM, Lipinski JM. Rede de apoio social de puérperas na prática da amamentação. Esc Anna Nery. 2015;19(2):310-5. doi: http://dx.doi.org/10.5935/1414-8145.20150042

27. Gerçek E, Karabudak SS, Çelik NA, Saruhan A. The relationship between breastfeeding self-eficacy and LATCH scores and affecting factors. J Clin Nurs. 2017;26(7-8):994-1004. doi: 10.1111/jocn.13423

28. Soares LS, Silva GRF, Gouveia MTO, Brandão EC, Oriá MOB. Aplicação da escala reduzida de auto eficácia em amamentação no contexto da Estratégia Saúde da Família. Enferm Foco [Internet]. 2014 [citado 2019 set. 20];5(3/4):49-52. Disponível em: http://biblioteca.cofen. gov.br/escala-reduzida-autoeficacia-amamentacao/

29. Aydin A, Pasinlioglu T. Reliability and validity of a Turkish version of the prenatal Breastfeeding Self-Efficacy Scale. Midwifery. 2018;64:116. doi: 10.1016/j.midw.2018.05.007

30. Lewallen LP. A review of instruments used to predict early breastfeeding attrition. J Perinat Educ. 2006;15(1):26-41. doi:10.1624/105812406X92967

31. Piro SS, Ahmed HM. Impacts of antenatal nursing interventions on mothers' breastfeeding self-efficacy: an experimental study. BMC Pregnancy Childbirth. 2020;20(1):19. doi: 10.1186/s12884-019-2701-0 